\title{
A novel peptide targeting Clec9a on dendritic cell for cancer immunotherapy
}

\author{
Zhongyi Yan ${ }^{1}$, Yahong $\mathbf{W u}^{1}$, Jiangfeng $\mathrm{Du}^{1}$, Guodong $\mathrm{Li}^{1}$, Shengdian Wang ${ }^{2}$, \\ Wenpeng Cao ${ }^{1}$, Xiuman Zhou ${ }^{1}$, Chunjing Wu${ }^{1}$, Dan Zhang ${ }^{1}$, Xueli Jing ${ }^{1}$, Yifan Li $^{1}$, \\ Hongfei Wang ${ }^{1}$, Yanfeng Gao ${ }^{1,3}$, Yuanming $\mathbf{Q i}^{1,3}$ \\ ${ }^{1}$ School of Life Sciences, Zhengzhou University, Zhengzhou, China \\ ${ }^{2}$ Institute of Biophysics, Chinese Academy of Sciences, Beijing, China \\ ${ }^{3}$ Collaborative Innovation Center of New Drug Research and Safety Evaluation, Zhengzhou, China \\ Correspondence to: Yanfeng Gao, email: gaoyf@zzu.edu.cn \\ Yuanming Qi, email: qym@zzu.edu.cn \\ Keywords: Clec9a, dendritic cells, cancer immunotherapy, peptide
}

Received: February 11,2016 Accepted: May 09, $2016 \quad$ Published: May 26, 2016

\section{ABSTRACT}

Dendritic cells (DCs) are professional antigen-presenting cells with antigen recognition molecules on the surface. Clec9a is selectively expressed on mouse CD8 ${ }^{+}$ DCs and $\mathrm{CD} 103^{+} \mathrm{DCs}$ subsets, which are functionally similar to human BDCA3+ DCs. It is reported that Clec9a is responsible for the antigen cross-presentation of these DC subsets. In the present study, by using phage display technique, we discovered a novel peptide WH, which can selectively bind to mouse FIt3L induced Clec9a+ DCs or Clec9a over-expressed HEK-293T cells. Furthermore, by using computer-aided docking model and mutation assay, we observed that $A_{s p}{ }^{248}$ and $\operatorname{Trp}^{250}$ are two key residues for Clec9a to bind with peptide WH. When coupled with OVA ${ }_{257-264}$ epitope, peptide WH can significantly enhance the ability of Clec9a+ DCs to activate OVA-specific CD8 ${ }^{+}$ $T$ cells, which elicit strong ability to secret IFN- $y$, express perforin and granzyme B mRNA. In B16-OVA lung metastasis mouse model, WH-OVA ${ }_{257-264}$ fusion peptide can also enhance the activation of $\mathrm{CDB}^{+} \mathrm{T}$ cells and decrease the lung metastasis loci. All these results suggested that peptide WH could be considered as an antigen delivery carrier targeting Clec9a+ DCs for cancer immunotherapy.

\section{INTRODUCTION}

Dendritic cells are the professional antigenpresenting cells (APCs) which play important roles in activation of naïve $\mathrm{CD} 8^{+} \mathrm{T}$ cell in response to foreign antigens or dead cell derived antigens [1, 2]. In mice, $\mathrm{CD} 8 \mathrm{a}^{+}$DCs (functionally similar to the BDCA $3^{+}$DCs in human) are the major subset for antigen cross-presentation which responsible for the activation of anti-tumor $\mathrm{CD} 8^{+}$ $\mathrm{T}$ cell response [3,4]. Therefore, it raises the possibility to design anti-tumor vaccines targeting this subset of DCs. Some specific C-type lectin members expressed on CD8a $\mathrm{a}^{+}$DCs, such as Clec9a (also named as DNGR-1) [3, 5], DEC205[6, 7] and Dectin-1 $[8,9]$, are reported to be responsible for antigen uptake. Among them, $\mathrm{Clec} 9 \mathrm{a}$ is uniquely expressed on mouse CD8 $\mathrm{a}^{+} \mathrm{DC}, \mathrm{CD} 103^{+} \mathrm{DC}$ and also some $\mathrm{pDC}[3,5]$. Correspondingly, Clec9a is also selectively expressed on human $\mathrm{BDCA}^{+} \mathrm{DC}$ [10-12].
Therefore, Clec9a is a very promising target to the DC vaccines for anti-tumor use.

Antigen targeting DCs via Clec9a could strongly enhance anti-tumor immunity [3, 4]. Other evidence also showed that antigen targeting Clec9a can enhance immune responses of $\mathrm{CD}^{+} \mathrm{T}$ cell, $\mathrm{CD} 8^{+} \mathrm{T}$ cell and $\mathrm{B}$ cell $[5,13,14]$. Interestingly, even in the absence of adjuvant, antigen targeting Clec9a can also promote potent humoral immunity and drive long effective development of follicular helper $\mathrm{T}$ cells, different from that of antigen targeting DEC205[13]. Further study indicated that the Clec9a can specifically recognize F-actin, a main component of the cellular cytoskeleton exposed by necrotic cells, and initiate cross priming of DCs to $\mathrm{CD}^{+}$ $\mathrm{T}$ cell response against dead cell-associated antigens [15-17]. These results suggested that Clec9a is a DCrestricted marker sensing damaged cells and antigens, thus targeting $\mathrm{Clec} \mathrm{a}^{+} \mathrm{DC}$ can promote humoral and 
cellular immunity. Actually, Clec9a antibody conjugated with antigen could enhance the cross priming of DC cells, and simulate cytotoxic T lymphocytes (CTLs) response to elicit anti-tumor effects $[3,18]$.

Considering that small peptides are more convenient to be conjugated to CTL epitopes by solid phase peptide synthesis methods, we proposed that small peptides could also be used as antigen carrier targeting Clec9a. To achieve this, we screened the Clec9a binding peptides by using phage display library. We found that a novel peptide WH can strongly bind to $\mathrm{Clec} 9 \mathrm{a}^{+} \mathrm{DCs}$ or $\mathrm{Clec} \mathrm{a}^{+}$over-expressed HEK-293 cells. By computer aided docking and mutation study, we further identified the key residues of Clec9a contact with peptide WH. We coupled peptide WH with model antigen peptide $\mathrm{OVA}_{257-264}$, and studied the cross priming of DCs to stimulate antigen specific CD8+ T cell response. In the B16-OVA lung metastasis mouse model, the CTL induction capacity and anti-tumor activity of the fusion peptide WH-OVA $\mathrm{W}_{257-264}$ were also investigated.

\section{RESULTS}

\section{Clec9a binding peptides screening and validating}

It was reported that the C-type lectin-like domain (CTLD) of Clec9a was important to the antigen recognition and endocytosis. Therefore, bio-panning was performed by using 12-mer peptide phage library targeting mouse Clec9a-CTLD fragment. After five rounds of biopanning, the exceptional enrichment of phage binders was obtained. After sequencing of the random selected 40 phage clones, four peptides were identified (Table 1). All the four corresponding phage clones can bind to the Clec9a-CTLD protein in the ELISA assay (Figure 1), especially the phages with the sequence of peptide WH. To investigate whether these four peptides could bind to Clec9a $\mathrm{a}^{+} \mathrm{DCs}$, bone marrow cells induced by Flt3L (FLDCs) were used. As shown in Figure 2A, Clec9a is highly expressed on Flt3L induced DCs, and only peptide WH could bind to FL-DCs. To further verify the binding ability of peptide $\mathrm{WH}$ to Clec9a, mClec9a-EGFP was overexpressed in HEK-293T cells. As shown in Figure 2B, peptide WH can not bind to the mock plasmid transfected HEK-293T cells. As expected, peptide WH but not the control peptide (GA) can bind to Clec9a $\mathrm{a}^{+} \mathrm{HEK}-293 \mathrm{~T}$ cells (Figure $2 \mathrm{C}$ ). The results suggested that peptide WH could selectively bind to Clec9a.

\section{The interaction between peptide WH and the Clec9a-CTLD fragment}

In silico approaches were applied to elucidate peptide binding model of Clec9a, of which the 3D structure was retrieved from protein data bank, and optimized by adding exclusive hydrogen atoms and the missing atoms to make the protein in protonated state. The $3 \mathrm{D}$ structure of peptide WH was created by using PEP-FOLD. Next, the $3 \mathrm{D}$ structure of peptide WH was unbiased docked to the optimized structure of Clec9a (UniProtKB: Q8BRU4) by using ZDOCK, which in turn created 50 most possible docking poses (WH/Clec9a complexes). The docked poses were analyzed and clustered into 2 groups: S1 and S2 (Supplementary Figure S1). The residues of Clec9a contact with peptide WH was listed in Supplementary Table S1.

The output of the in silico prediction guided side-directed mutagenesis experiments, which was retrospectively used to verify the quality of the peptide binding model. The docking poses suggested that seven residues of Clec9a may play crucial role in peptide binding. Therefore, mutagenesis experiments were conducted and seven Clec9a mutants were expressed on HEK-293T cells. As shown in Figure 3A, when the residue $\mathrm{Asp}^{248}\left(\mathrm{D}^{248}\right)$ or $\operatorname{Trp}^{250}\left(\mathrm{~W}^{250}\right)$ of Clec9a was mutated to alanine, the binding activity of peptide WH was greatly impaired. Echoing to the peptide WH/Clec9a docking model, the residue $\mathrm{W}^{250}$ can interact with five residues of peptide WH $\left(\mathrm{Arg}^{3}, \mathrm{Phe}^{4}, \mathrm{Ser}^{7}, \mathrm{Val}^{8}\right.$ and $\left.\mathrm{Thr}^{11}\right)$, and $\mathrm{D}^{248}$ can interact with $\mathrm{Arg}^{3}$ and $\mathrm{Phe}^{4}$ of peptide WH (Figure 3B). The results also showed that $\mathrm{Arg}^{3}$ and $\mathrm{Phe}^{4}$ of peptide $\mathrm{WH}$ are the major residues interact with $\mathrm{D}^{248}$ and $\mathrm{W}^{250}$ of Clec9a, with less than $4.5 \AA$ distance (Figure 3B). These results further confirmed that peptide $\mathrm{WH}$ could bind to Clec9a specifically.

\section{Peptide WH enhances OVA ${ }_{257-264}$ cross presentation by Clec9a ${ }^{+}$DCs}

Since Clec9a is highly expressed on Flt3L induced DCs, FL-DCs are always considered as the surrogate of CD8 $\mathrm{a}^{+} \mathrm{DCs}$. To see whether peptide WH could enhance the cross-presentation of $\mathrm{OVA}_{257-264}$ antigen, the fusion peptide WH-OVA $_{257-264}$ and GA-OVA ${ }_{257-264}$ control were synthesized. As shown in Figure 4, after incubation with WH-OVA $_{257-264}$, FL-DCs could strongly stimulate the IFN- $\gamma$ release from OT- $1 \mathrm{CD}^{+} \mathrm{T}$ cells. This activation effects are more potent than that of the control peptide GA-OVA $_{257-264}$ or $\mathrm{OVA}_{257-264}$ alone. WH-OVA W57-264 $_{\text {treated }}$ FL-DCs can also stimulate the proliferation of OT- 1 cells. We also detected the mRNA expression of CTL killing markers perforin and granzyme B by qRT-PCR. The mRNA expression of granzyme $\mathrm{B}$ of $\mathrm{WH}^{-O \mathrm{OVA}_{257-264}}$ group is about 5-fold higher than that of GA-OVA $257-264$. These results suggested that the peptide $\mathrm{WH}$ can deliver antigen to $\mathrm{Clec} 9 \mathrm{a}^{+} \mathrm{DCs}$, enhance the antigen cross-presentation, and thus promote $\mathrm{T}$ cell activation.

\section{Peptide WH enhances OVA ${ }_{257-264}$ antigen specific CTL cross priming in vivo}

Since peptide WH can enhance antigen cross priming in vitro, we wonder if this peptide can also act as 
a vaccine carrier and promote the antigen-specific CTLs induction in vivo. After immunization of the mice with peptide $\mathrm{WH}-\mathrm{OVA}_{257-264}$ or controls for three times, the splenocytes were re-stimulated with $\mathrm{OVA}_{257-264}$ to detect the CTL response via IFN- $\gamma$ secretion and CTL killing markers expression, such as perforin and granzyme B. As shown in Figure 5, peptide WH-OVA ${ }_{257-264}$ can strongly stimulate supernatant and intracellular IFN- $\gamma$ secretion compared with the control groups. In the intracellular IFN- $\gamma$ staining assay, WH-OVA ${ }_{257-264}$ significantly enhance the induction of $\mathrm{OVA}_{257-264}$ specific $\mathrm{CD}^{+} \mathrm{T}$ cell response. Also, the mRNA expression of perforin and granzyme B was both increased. All these data indicated that peptide WH can enhance the cross presentation of antigen $\mathrm{OVA}_{257-264}$ in vivo and has the potential to be used as a vaccine carrier.

\section{Peptide WH enhances antitumor effects of OVA $_{257-264}$}

To investigate whether the fusion peptide WH-OVA $_{257-264}$ could be used as a vaccine for the immunotherapy of cancer metastasis, the lung metastasis model of B16-OVA was established. As shown in

Table 1: Clone frequency and peptide sequences of the selected phages

\begin{tabular}{lcc}
\hline Phage & Peptide sequence & Phage frequency \\
\hline IH & IKTGPASLQNPH & $20 / 40$ \\
WH & WPRFHSSVFHTH & $4 / 40$ \\
RW & RPHRNGGRDQTW & $2 / 40$ \\
SR & SAHNPSSLTGSR & $2 / 40$ \\
\hline
\end{tabular}

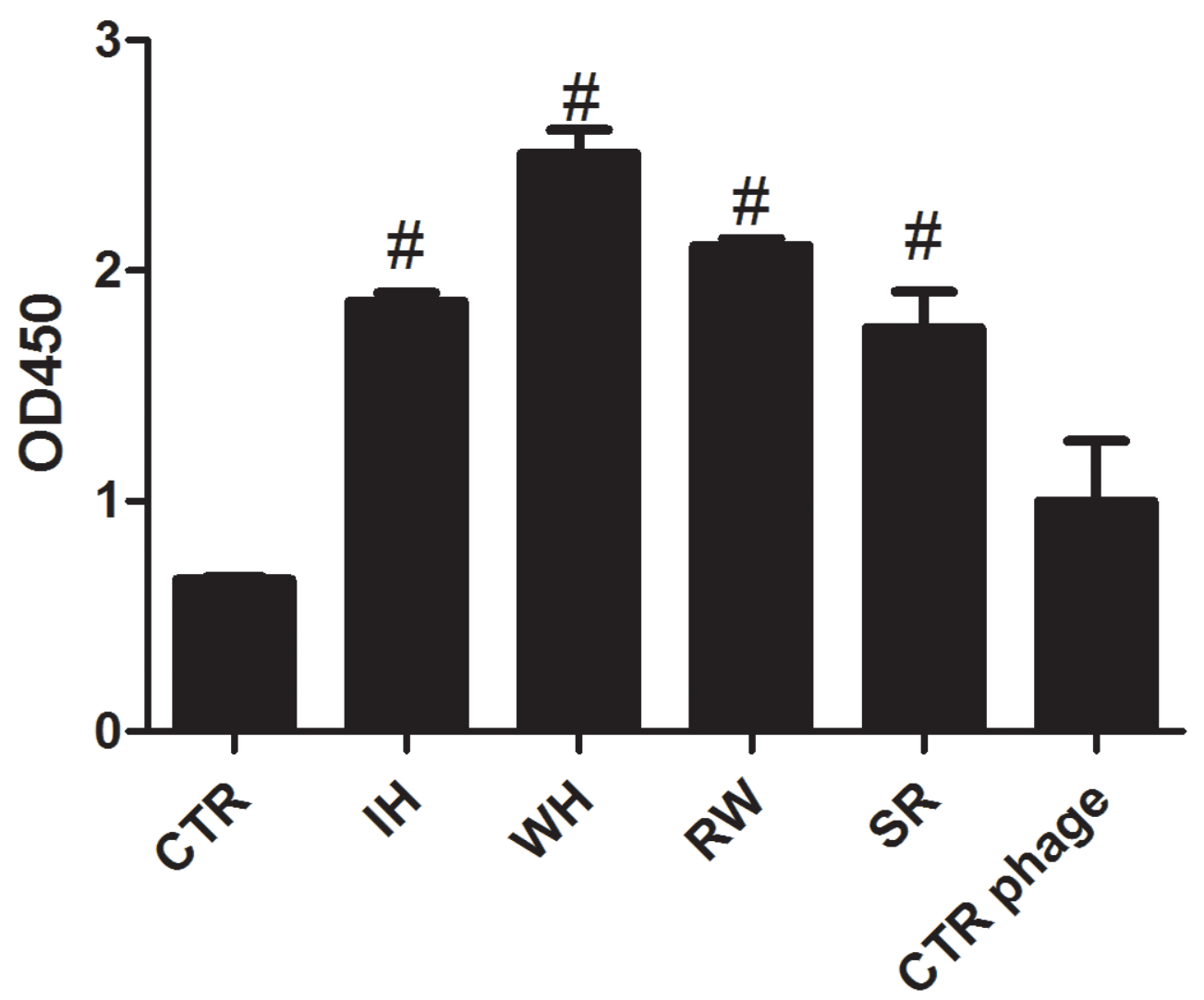

Figure 1: ELISA of the selected phage clones toward Clec9a-CTLD protein. $10 \mu$ g Clec9a-CTLD protein was coated into the ELISA plate at $4{ }^{\circ} \mathrm{C}$ overnight. The next day, the plate was washed 3 times with TBS buffer containing $0.05 \%$ Tween 20 and blocked with $5 \%$ BSA buffer. $1 \times 10^{7}$ phages were added for 2 hours at room temperature. The anti-M13 protein with HRP and $1 \times \mathrm{TMB}$ buffer were used. Finally, $50 \mu \mathrm{L} 1 \mathrm{mM} \mathrm{H}_{3} \mathrm{PO}_{4}$ stop buffer was added and plate was read at $450 \mathrm{~nm}$. \#: twice higher than control group (CTR, without phage). CTR phage: phage that do not have random peptide sequence inserted. 

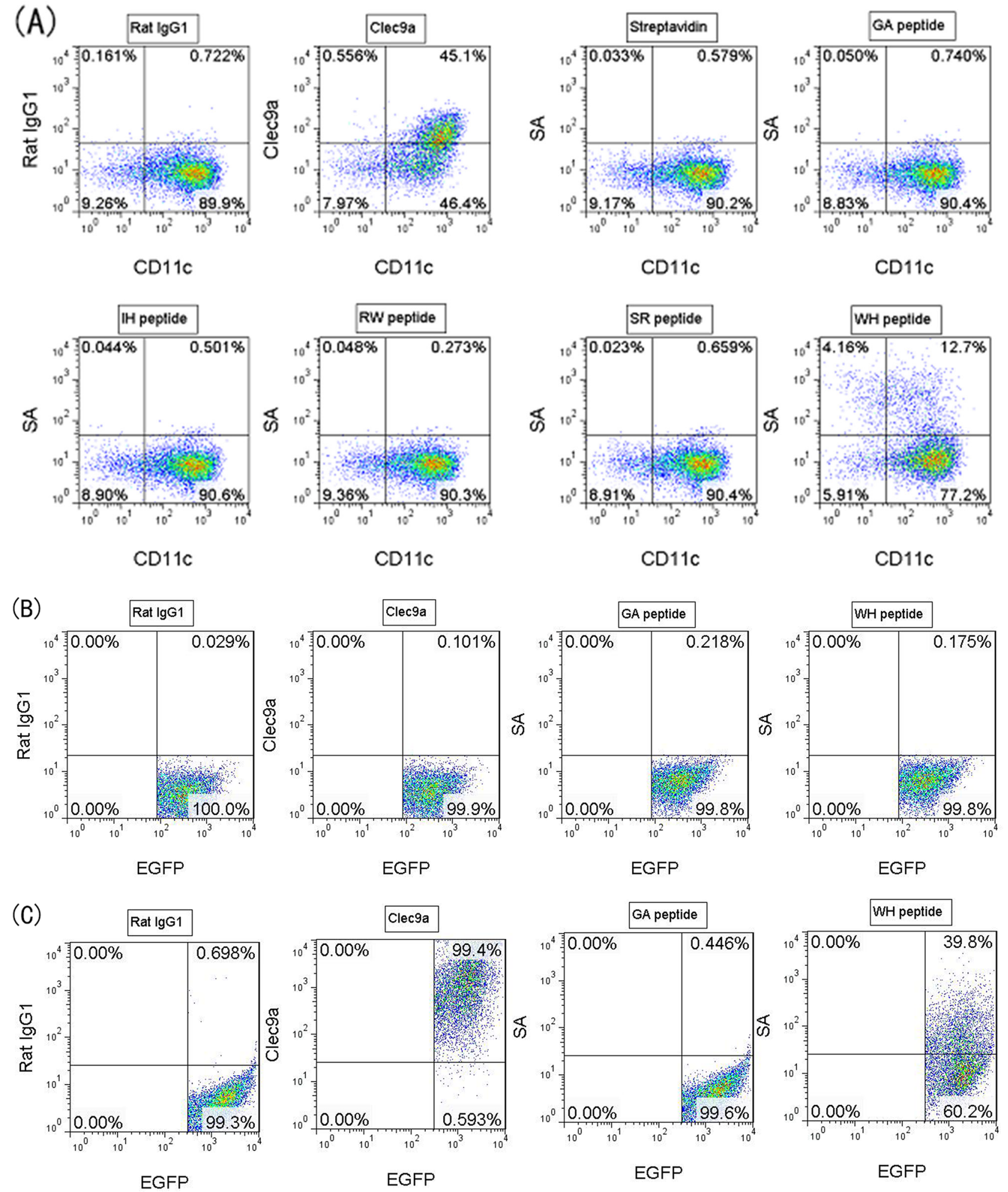

Figure 2: Binding of peptides toward Clec9a $\mathbf{a}^{+}$FL-DCs or transfected HEK-293T cells. Each biotinylated peptide was incubated with FL-DCs (or transfected HEK-293T cells) at $4^{\circ} \mathrm{C}$ for $30 \mathrm{~min}$, washed 3 times with FACS buffer containing $2 \mathrm{mM}$ EDTA, and then streptavidin-PE (SA) was added to stain the peptide binding to FL-DCs (or transfected HEK-293T cells) at $4{ }^{\circ} \mathrm{C}$ for another $30 \mathrm{~min}$. After Washing twice, the cells were analyzed by flow cytometry. Peptide GA was used as peptide control, and Rat IgG1 was used as isotype control. A. Clec9a was expressed on DCs induced by 200ng/mL Flt3L (FL-DCs). Peptide WH but not other peptides can bind to FL-DCs. B. HEK-293T was transfected with the pIRES2-EGFP plasmid (mock vector) by using calcium phosphate cell transfection method. Peptide WH can not bind to the mock transfectant (pIRES2-EGFP) Clec9a- HEK-293T cells. C. HEK-293T was transfected with the pIRES2EGFP-mClec9a plasmid by using calcium phosphate cell transfection method. Peptide WH can bind to Clec9a ${ }^{+}$HEK-293T cells. 

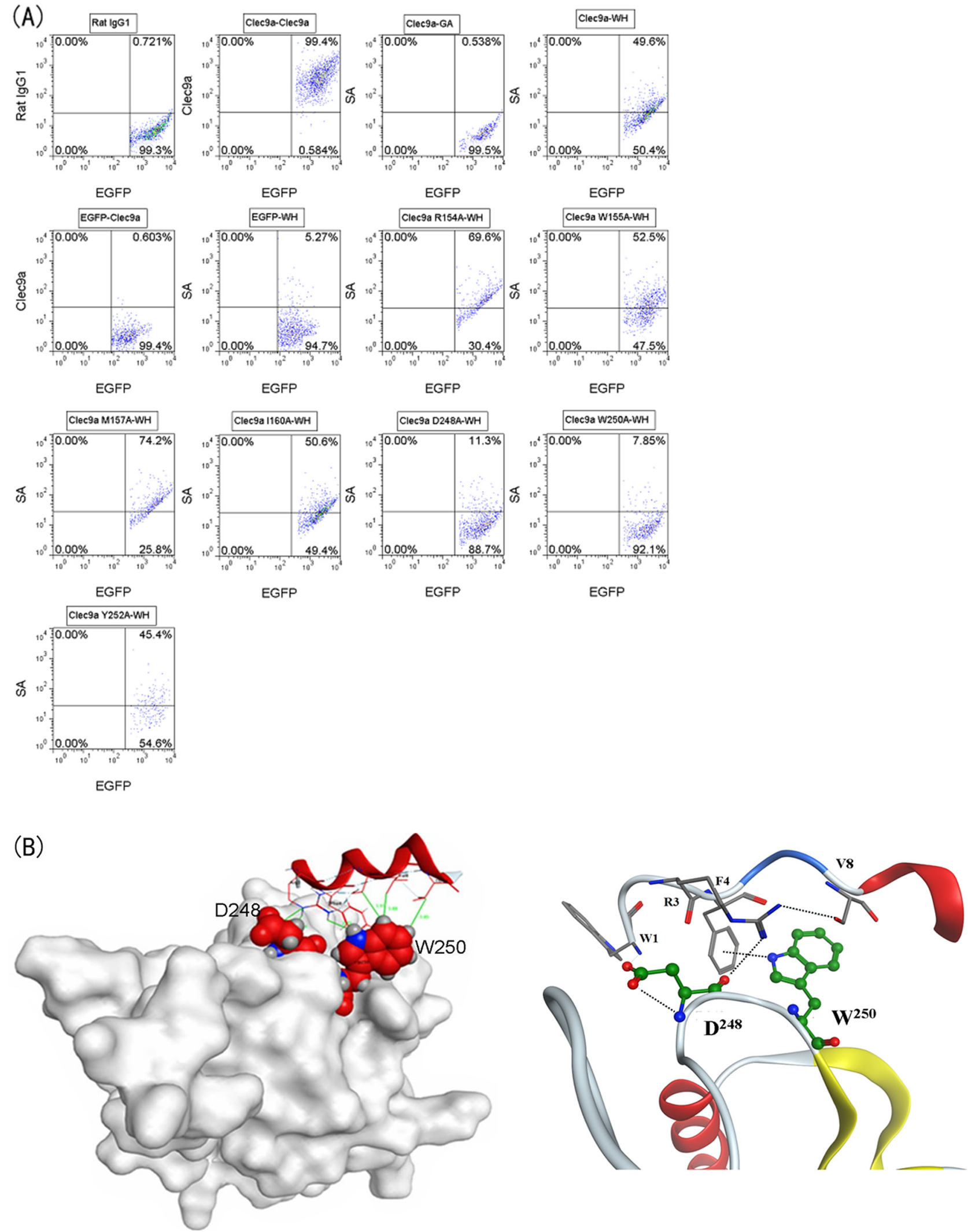

Figure 3: Binding of peptide WH toward Clec9a mutants and the docking model. PEP-FOLD was used to mimic the structure of peptide $\mathrm{WH}$, and then these structures were docked to mouse Clec9a crystal structure for predicting the key binding residues of Clec9a. A. Seven Clec9a single amino acid mutation plasmids were transfected into HEK-293T cells. The staining procedure was same as that described in Figure 2. B. The left figure showed the docking model of peptide WH with mClec9a. The right figure showed that the key interaction forces less than $4.5 \AA$ of peptide $\mathrm{WH}$ bind to $\mathrm{D}^{248}$ or $\mathrm{W}^{250}$ of Clec9a. 

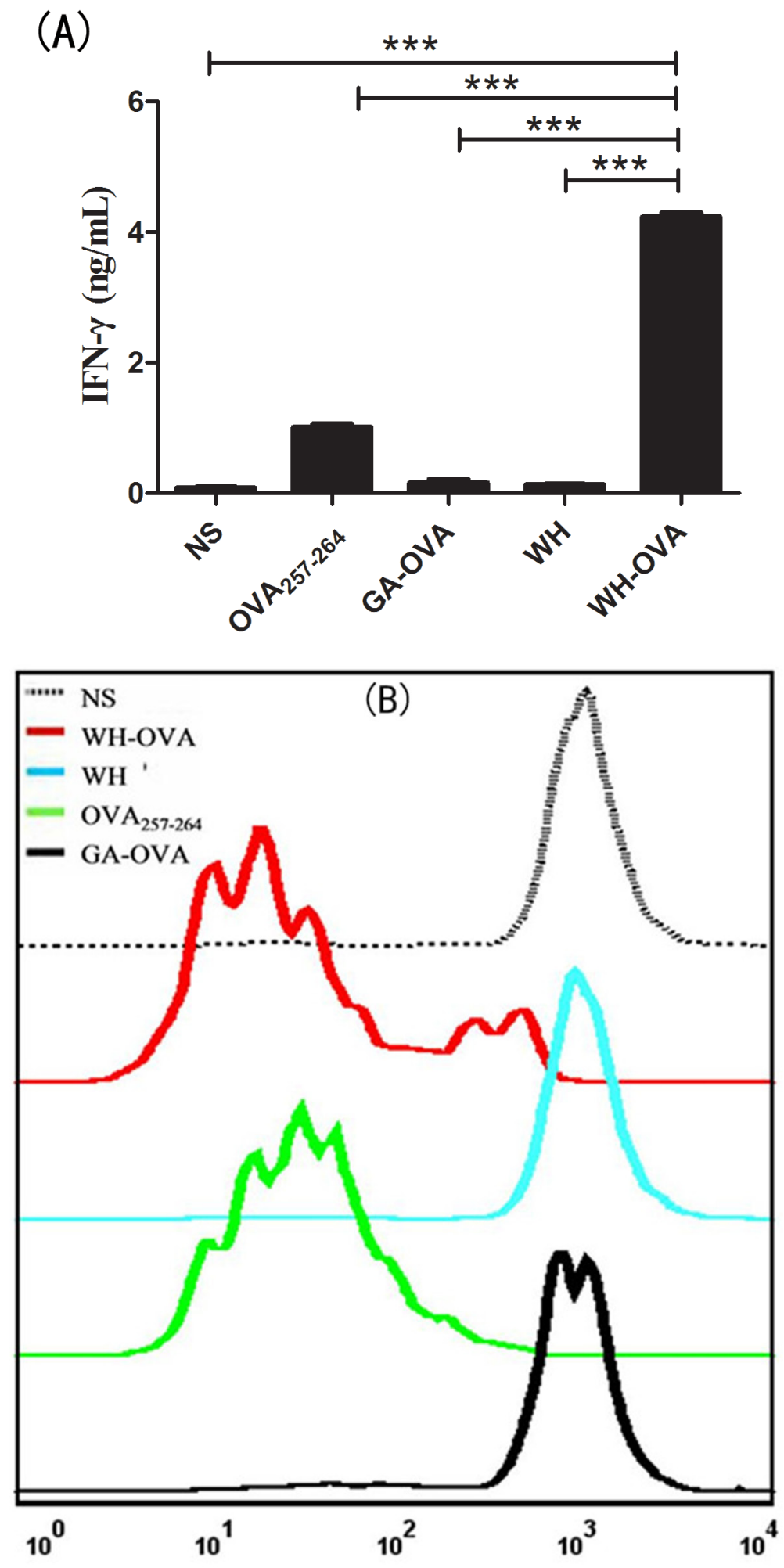

\section{CFSE}

Figure 4: The effects of peptide WH on the cross-presentation of OVA ${ }_{257-264}$ by FL-DCs in vitro. FL-DCs were pulsed with different peptides $(10 \mu \mathrm{g} / \mathrm{mL})$ or normal saline at $4^{\circ} \mathrm{C}$ for $1.5 \mathrm{~h}$, and then washed 3 times with medium. Isolated lymph node $\mathrm{CD} 8^{+} \mathrm{T}$ cells from OT-1 mice were labeled with $2 \mu \mathrm{M}$ CFSE for 10min at room temperature, and washed 3 times with medium. The $1 \times 10^{5} \mathrm{CFSE}$ stained $\mathrm{CD} 8^{+} \mathrm{T}$ cells were incubated with different peptides pulsed $1 \times 10^{4} \mathrm{FL}-\mathrm{DCs}$ for $72 \mathrm{~h}$. A. The IFN $\gamma$ of the supernatant determined by ELISA. B. Proliferation of $\mathrm{CD} 8^{+} \mathrm{T}$ cells stimulated by peptide pulsed FL-DCs. (Continued) 
(C)
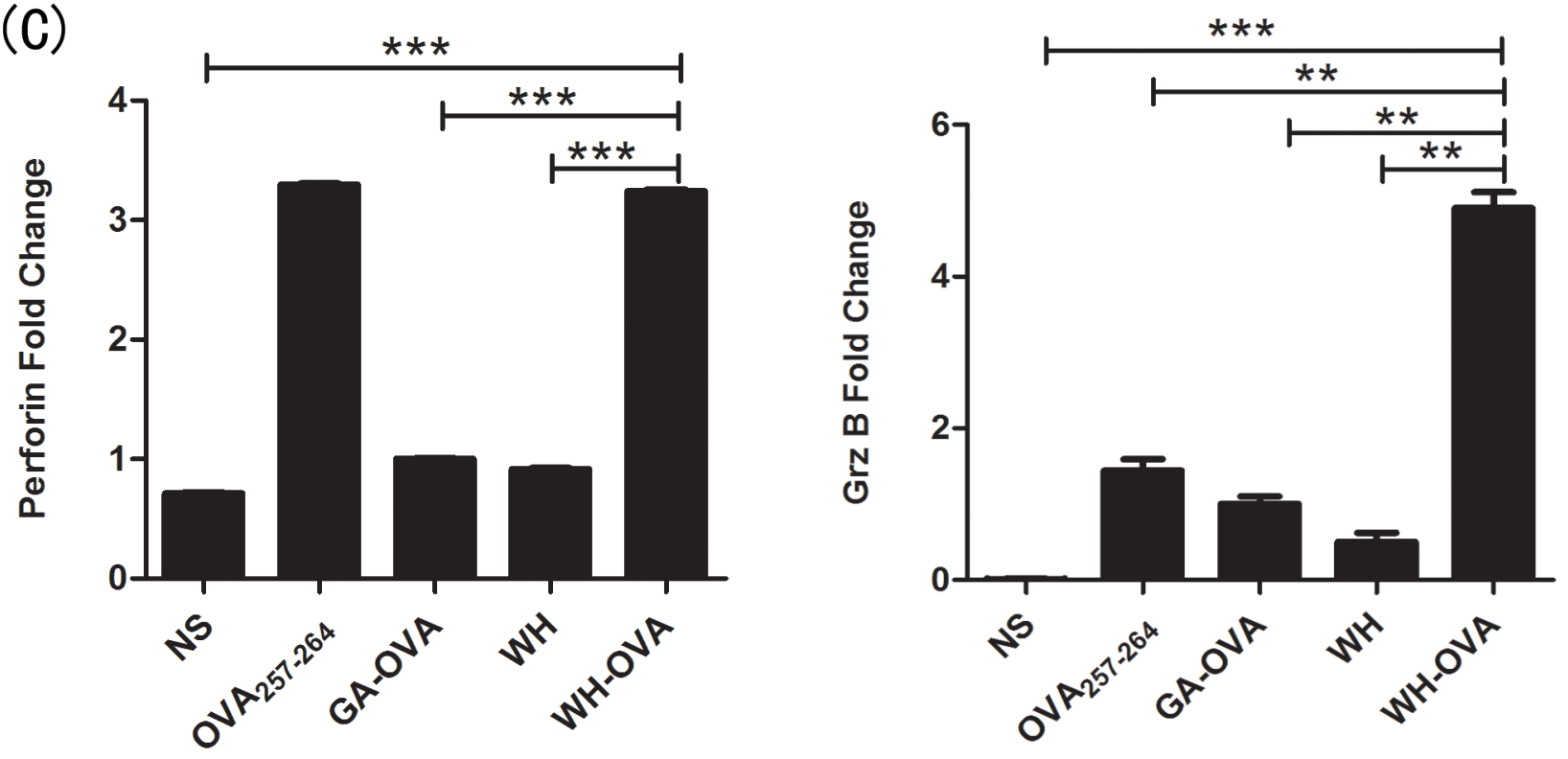

Figure 4: (Continued) The effects of peptide WH on the cross-presentation of OVA ${ }_{257-264}$ by FL-DCs in vitro. C. The perforin and granzyme B (Grz B) mRNA expression fold change compared to the control peptide GA-OVA $257-264$ group. Data are presented as means $\pm \mathrm{SEM}, * * P<0.01, * * * P<0.001$. Data are representative of three experiments.

(A)

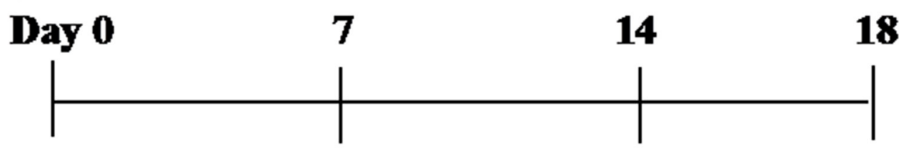

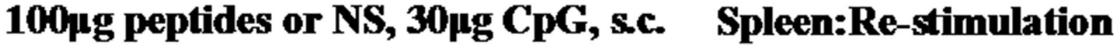

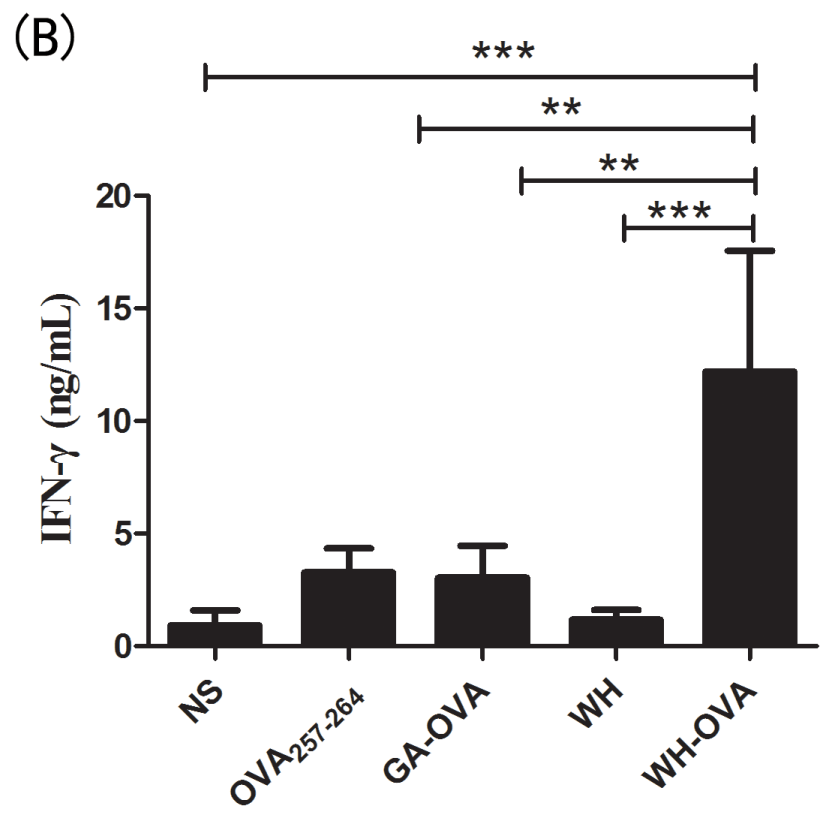

Figure 5: The effects of peptide $\mathrm{WH}$ on the cross priming of $\mathrm{OVA}_{257-264}$ specific $\mathrm{CDB}^{+} \mathrm{T}$ cells in naïve $\mathrm{C57Bl} / 6 \mathrm{~J}$ mice. $100 \mu \mathrm{g}$ WH-OVA/OVA $257-264 / \mathrm{WH} / \mathrm{GA}-\mathrm{OVA}$ or normal saline (NS) was injected s.c. with CpG ODN $1826(30 \mu \mathrm{g})$ weekly for three times, then the splenocytes were isolated and re-stimulated by $\mathrm{OVA}_{257-264}(10 \mu \mathrm{g} / \mathrm{mL})$ for 5 days. A. The scheme of the immunization and process. B. Supernatant IFN- $\gamma$ determined by ELISA. (Continued) 

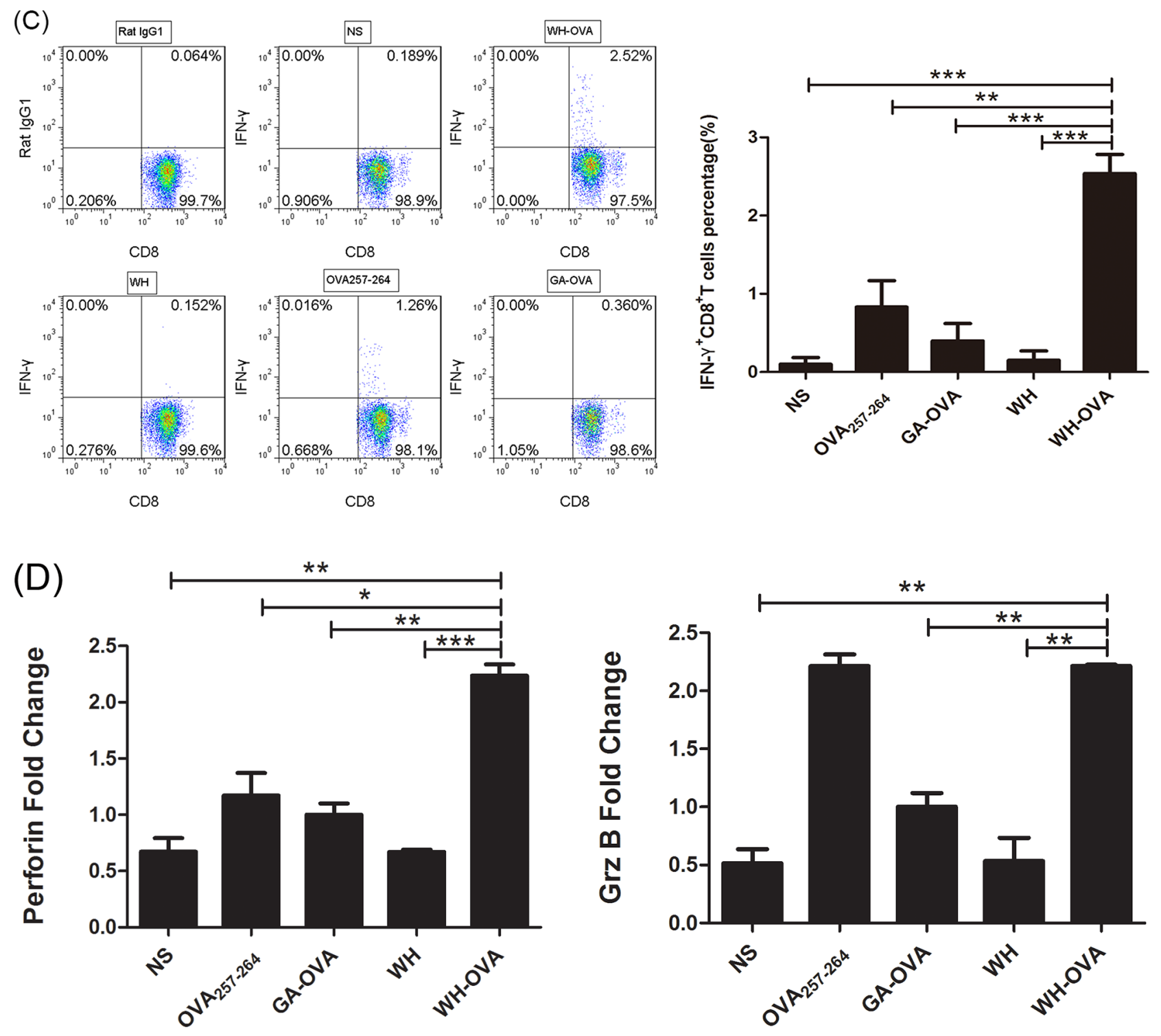

Figure 5: (Continued) The effects of peptide WH on the cross priming of $\mathrm{OVA}_{257-264}$ specific $\mathrm{CD8}^{+} \mathrm{T}$ cells in naïve C57BI/6J mice. C. The frequencies of IFN- $\gamma$ released by $\mathrm{OVA}_{257-264}$ specific $\mathrm{CD} 8^{+} \mathrm{T}$ cells analyzed by flow cytometry intracellular staining. The histogram showed the statistical results. D. The perforin and granzyme B mRNA expression fold change compared to the control peptide $\mathrm{GA}_{-} \mathrm{OVA}_{257-264}$ group. Data are presented as means $\pm \mathrm{SEM}(\mathrm{n}=5),{ }^{*} P<0.05, * * P<0.01, * * * P<0.001$. Data are representative of two experiments.

Figure 6, the number of lung metastasis loci was significantly decreased in the group treated with $\mathrm{WH}-$ $\mathrm{OVA}_{257-264}$ compared to that of control group. In the tumor bearing mice, WH-OVA $257-264$ could strongly stimulate IFN- $\gamma$ production of the splenocytes than that of control groups (GA-OVA, $\mathrm{OVA}_{257-264}$ or WH peptide). Furthermore, WH-OVA $_{257-264}$ treatment can induce CTL killing markers perforin and granzyme B mRNA expression. Overall, the results suggested that peptide $\mathrm{WH}$ as a promising vaccine carrier can stimulate antigen specific CTL cross-priming and enhance anti-tumor immunotherapy.

\section{DISCUSSION}

Dendritic cells based vaccines are one of the most promising candidates for cancer immunotherapy [19, 20]. Application of tumor associated antigens pulsed DC vaccines has achieved some success [21]. But most of these vaccines could not induce strong $\mathrm{T}$ cell response. One reason is that these antigens can not be well uptaken and presented by DCs. To overcome this, researchers discovered a series of potential molecules on the surface of DCs, which could help DCs to recognize, uptake and 
process antigens. Among these molecules, C-type lectin members, such as DEC205[22-25], Clec9a [3-5, 15, 26] and Dectin-1 [8, 9, 27, 28] are extensively studied. Clec9a is selectively expressed on CD8a $\mathrm{a}^{+} \mathrm{DCs}$ (mouse) and $\mathrm{BDCA}^{+} \mathrm{DC}$ (human), the subsets with the most strongest ability to the cross-presentation of antigens. It was reported that Clec9a antibody conjugated with antigens targeting $\mathrm{Clec} 9 \mathrm{a}^{+} \mathrm{DC}$ could promote the antigen cross presentation and enhance antitumor immunotherapy $[3,5,13,18,29]$. To take the advantage of small peptides which could be conveniently synthesized with epitopes or fused with protein antigens, we performed the widely used phage display method to screen Clec9a binding peptides. Then we tested its ability to act as an antigen carrier targeting $\mathrm{Clec} 9 \mathrm{a}^{+} \mathrm{DCs}$ both in vitro and in tumor bearing mice.

The newly discovered peptide WH can bind to Flt3L induced DCs or mClec9a $\mathrm{a}^{+}$HEK-293T cells.
This binding activity is correlated to the expression of Clec9a. Moreover, peptide WH can not binding the tested murine cell lines, such as B16, B16-F10, S180, CT26, H22, RAW264.7 and NIH3T3 (data not shown). We also conducted mutagenesis experiment and identified that the residues $\mathrm{D}^{248}$ and $\mathrm{W}^{250}$ were crucial for peptide $\mathrm{WH}$ binding. The results were further confirmed by unbiased docking study through PEP-FOLD and ZDOCK. The results were consistent to the previous report that mutation of $\mathrm{W}^{250}$ of Clec9a significantly impaired F-actin recognition [16]. All these results suggested that peptide $\mathrm{WH}$ could selectively and specifically bind to Clec9a.

WH-OVA $_{257-264}$ treated FL-DCs can significantly stimulate $\mathrm{CD}^{+} \mathrm{T}$ cells to release IFN- $\gamma$ compared to that of GA-OVA ${ }_{257-264}$ or $\mathrm{OVA}_{257-264}$ alone. Also, $\mathrm{CD}^{+} \mathrm{T}$ cells simulated by WH-OVA $257-264$ treated FL-DCs exhibit good proliferation, express high level of perforin and

(A)
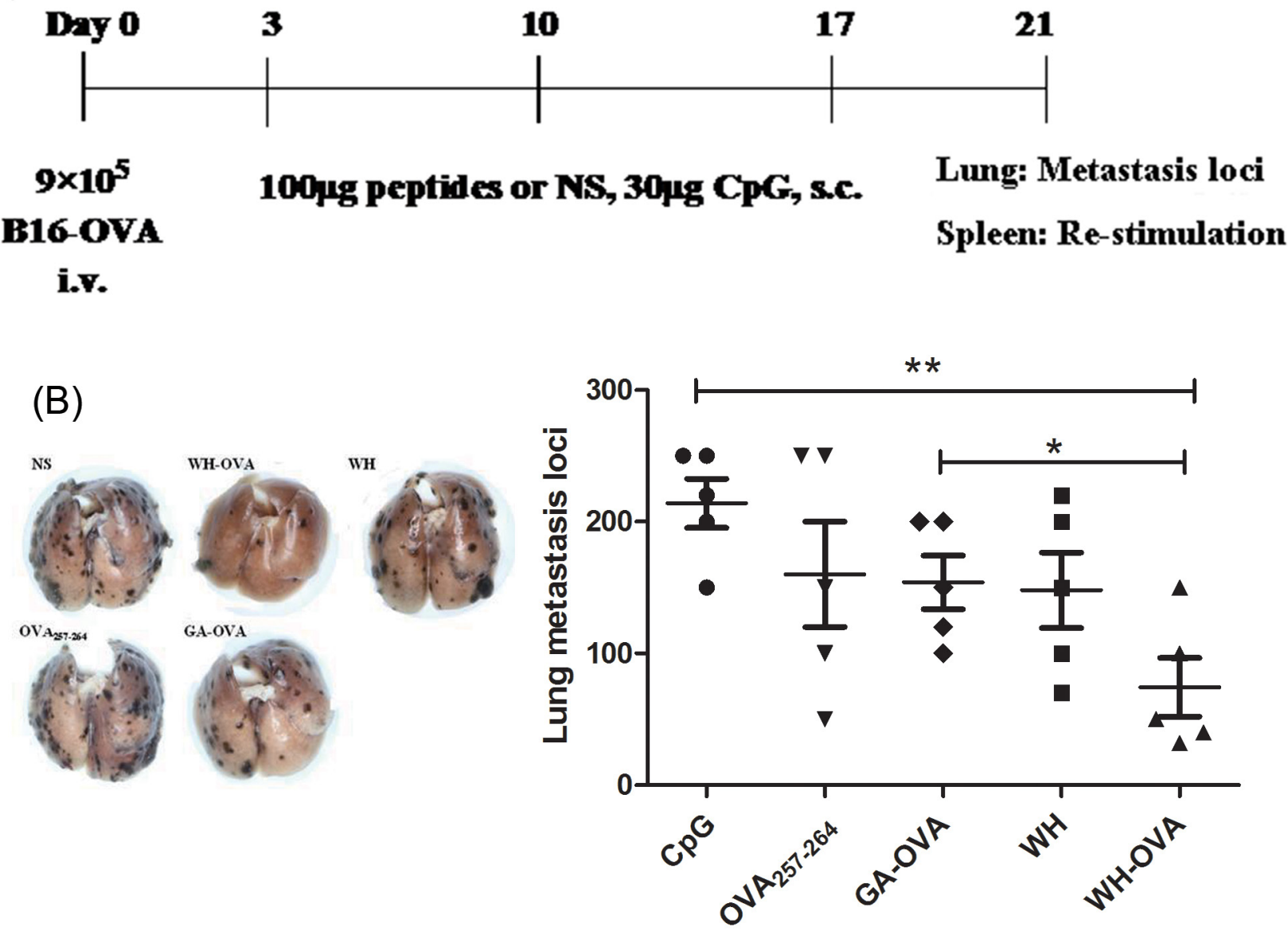

Figure 6: The antitumor effects of peptide $\mathrm{WH}-\mathrm{OVA}_{257-264}$ in B16-OVA melanoma lung metastasis model. $9 \times 10^{5} \mathrm{~B} 16-$ OVA melanoma cells were injected intravenously in C57Bl/6J mice to establish the lung metastasis model. 3 days later, 100 $\mu \mathrm{g}$ WH-OVA/ $\mathrm{OVA}_{257-264} / \mathrm{WH} / \mathrm{GA}-\mathrm{OVA}$ or NS was injected s.c. with CpG ODN $1826(30 \mu \mathrm{g})$ weekly for three times, then the lungs were processed to count the metastasis loci, and the splenocytes were isolated and re-stimulated by OVA $257-264(10 \mu \mathrm{g} / \mathrm{mL})$ for 5 days. A. The scheme of tumor model, immunotherapy and ex vivo analysis. B. The effects of peptide $\mathrm{WH}-\mathrm{OVA}_{257-264}$ on the number of lung metastasis loci. (Continued) 

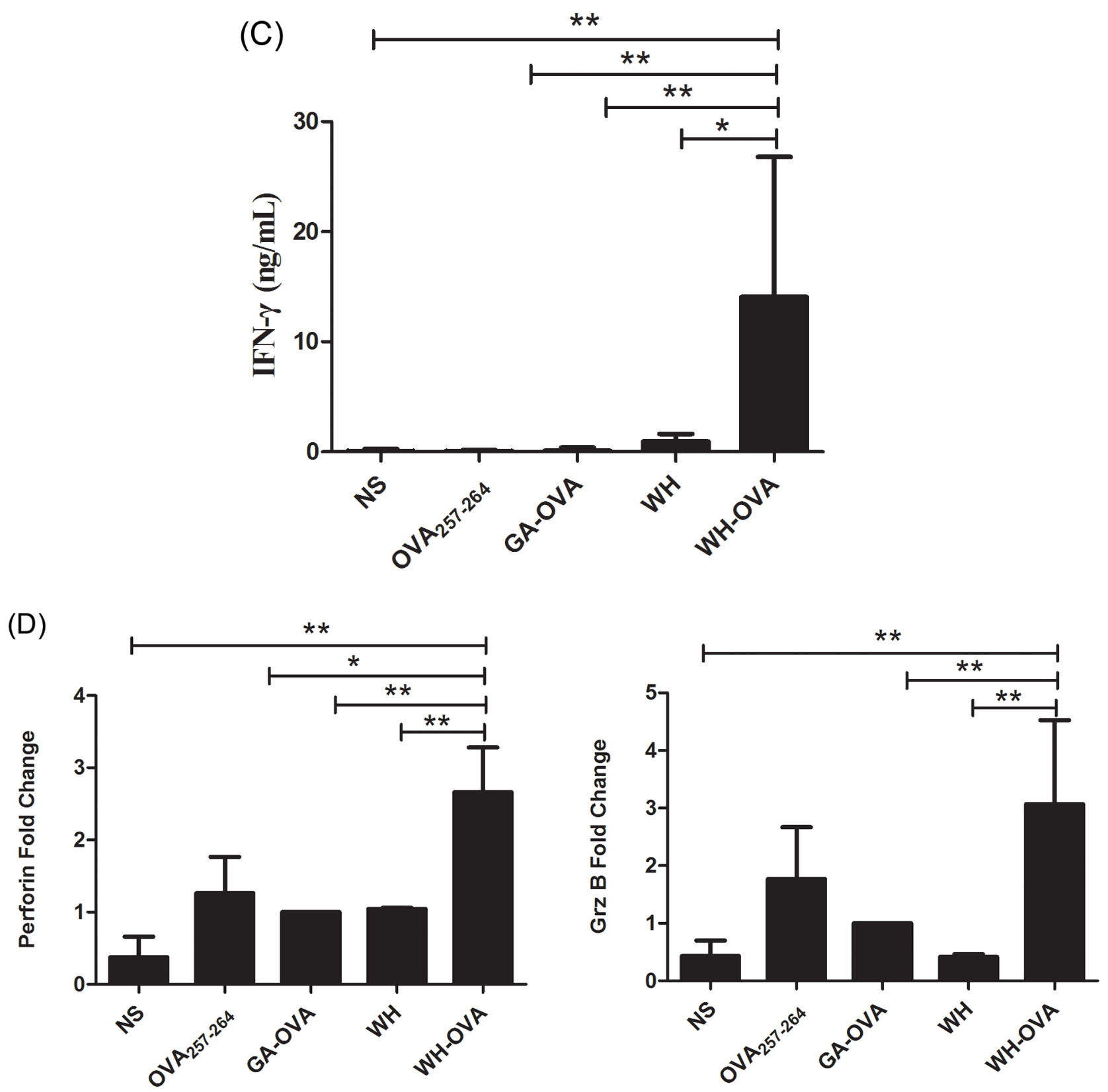

Figure 6: (Continued) The antitumor effects of peptide WH-OVA ${ }_{257-264}$ in B16-OVA melanoma lung metastasis model. C. Supernatant IFN- $\gamma$ determined by ELISA. D. The perforin and granzyme B mRNA expression fold change. Data are presented as means $\pm \operatorname{SEM}(\mathrm{n}=5),{ }^{*} P<0.05, * * P<0.01$. Data are representative of two experiments.

granzyme B. When immunizing WH-OVA ${ }_{257-264}$ in mice, antigen specific $\mathrm{CD}^{+} \mathrm{T}$ cell response could be induced, which indicated that peptide WH could enhance the cross presentation of $\mathrm{OVA}_{257-264}$ epitope in vivo.

Then, by using lung metastasis tumor bearing mice model, we found that peptide WH could greatly enhance the $\mathrm{OVA}_{257-264}$ antigen specific $\mathrm{T}$ cell response and decrease the lung metastasis loci. Our results suggested that peptide WH could be very powerful to be used as antigen carrier to help the anti-tumor immunotherapy of DC vaccines. Compared to the anti-Clec9a antibody, this short peptide is very convenient to be synthesized and conjugated to the antigen epitope. In our lab we are also trying to combine this strategy with checkpoint blockade inhibitors to further enhance the antitumor effects [30].

In conclusion, a novel peptide targeting Clec9a was identified by phage display bio-panning. Peptide WH could bind to Clec9 $\mathrm{a}^{+}$DCs selectively, and enhance the antigen cross presentation, further stimulate the antigen specific CTL response both in vitro and in vivo. This strategy could be very effective in cancer immunotherapy. 


\section{MATERIALS AND METHODS}

\section{Mice}

C57Bl/6J (Beijing HFK Bioscience Co., China) and OT-1 mice were bred at Zhengzhou University in specific pathogen-free facility. All animal experiments were performed in accordance with national and institutional guidelines for animal care, and were approved by Ethics Committee of Zhengzhou University.

\section{Cells}

Mouse B16 melanoma cell line was obtained from the Type Culture Collection of the Chinese Academy of Science (Shanghai, China). OVA antigen transgenic cell line B16OVA was maintained in Prof. Shengdian Wang's lab. B16 and B16-OVA cells were cultured in RPMI 1640. HEK293T cells were cultured in DMEM. For FL-DC induction, mouse BMDCs were generated by culturing bone marrow cells in RPMI 1640 supplemented with 200ng/mL Flt3L (eBioscience, USA) for 10 12 days with semi-medium changing every 4 days. Splenocytes were prepared from C57BL/6J by removing red blood cells (RBCs, $0.168 \mathrm{M}$ $\mathrm{NH}_{4} \mathrm{Cl} ; 5$ minutes on ice). $\mathrm{CD} 8 \mathrm{a}^{+} \mathrm{T}$ cells of OT-1 mice were isolated from lymph nodes by using EasySep ${ }^{\mathrm{TM}}$ Mouse CD8 ${ }^{+}$ T Cell Isolation Kit (Stemcell Technologies). All the culture medium was supplemented with $10 \%$ fetal calf serum (BI), penicillin, streptomycin, glutamine, and 2-macraptoethanol (Life technology), and cells were cultured at $37^{\circ} \mathrm{C}$ in $5 \% \mathrm{CO}_{2}$.

\section{Protein expression and mutation}

The $3 \times$ FLAG-mClec9a-CTLD plasmid was a kind gift from Professor Caetano Reis e Sousa and Kathryn Snelgrove [15]. The mClec9a-CTLD fragment was expressed by HEK-293T cells, and then purified by anti-FLAG (M2) beads (Sigma) and size-exclusion chromatography pre-packed Superdex 200 (GE). In the cellular binding experiments, Clec9a gene was cloned from splenocyte cDNA of $\mathrm{C} 57 \mathrm{Bl} / 6 \mathrm{~J}$ mice and constructed into pIRES2-EGFP vector (Biofeng, China). The forward primer: 5'-CCCTCGAGATGCATGCGGAAGAAATAT ATACCTC-3'; reverse primer: 5'-CGGAATTCTCAGA TGCAGGATCCAAATGC-3'. The recombinant plasmid was expressed in HEK-293T cells for peptides binding experiments. For peptide WH/Clec9a interaction study, PEP-FOLD was used to predict the peptide 3D structures of the peptide, and then the top 50 peptide WH structures were used to dock with the optimized Clec9a unbiasly by using ZDOCK. Most of the docked poses located in S1 $\left(\mathrm{R}^{154}\right.$, $\mathrm{E}^{156}, \mathrm{M}^{157}, \mathrm{~N}^{159}, \mathrm{I}^{160}, \mathrm{~S}^{161}, \mathrm{~K}^{163}, \mathrm{~S}^{164}, \mathrm{~K}^{167}, \mathrm{C}^{247}, \mathrm{D}^{248}$ and $\mathrm{W}^{250}$ ) or S2 $\left(\mathrm{E}^{153}, \mathrm{~W}^{155}, \mathrm{~K}^{191}, \mathrm{~N}^{194}, \mathrm{~S}^{249}\right.$, and $\left.\mathrm{Y}^{252}\right)$ area of Clec9a. Top 10 poses of $\mathrm{WH} / \mathrm{Clec} 9 \mathrm{a}$ complexes were selected to statistically calculate the occurrence of residues in binding of Clec9a (Supplementary Table S1). The main residues of Clec9a for the interaction with peptide $\mathrm{WH}$ were $\mathrm{R}^{154}, \mathrm{~W}^{155}$,
$\mathrm{M}^{157}, \mathrm{I}^{160}, \mathrm{D}^{248}, \mathrm{~W}^{250}$ and $\mathrm{Y}^{252}$. Each of these residues was mutated to alanine by using quick change method by using the pIRES2-mClec9a plasmid as template. The primers were shown in Supplementary Table S2.

\section{Bio-panning of mClec9a protein binding phages}

The Ph.D. ${ }^{\text {TM }}$-12 Phage Display Peptide Library Kit was purchased from New England Biolabs (NEB, Beijing, China). The panning experiment was conducted according to the manufacturer's instructions. Briefly, $100 \mu \mathrm{g} / \mathrm{mL}$ mClec9a protein was coated onto a 96-well plate overnight at $4^{\circ} \mathrm{C}$ with gentle agitation in a humidified container in $0.1 \mathrm{M} \mathrm{NaHCO}_{3} \mathrm{pH} 8.6$ solution. After washing with Trisbuffered saline (TBS containing $0.1 \%$ Tween 20 ), $0.1 \mathrm{M}$ $\mathrm{NaHCO}_{3} \mathrm{pH} 8.6$ blocking buffer containing $5 \mathrm{mg} / \mathrm{mL}$ BSA was added for $3 \mathrm{~h}$ incubation at $4^{\circ} \mathrm{C}$. After washing with TBST, $10^{13} \mathrm{pfu}$ phages were added for $1 \mathrm{~h}$ incubation at $25^{\circ} \mathrm{C}$ with gentle shaking. Then the unbound phages were removed. $200 \mu \mathrm{L} 0.2 \mathrm{M}$ Gly- $\mathrm{HCl}(\mathrm{pH} 2.2$ with $0.1 \% \mathrm{BSA}$ ) was used to harvest the binding phages. After five rounds bio-panning, 40 phage clones were selected randomly and sequenced.

\section{Peptide synthesis}

Peptides were synthesized in our lab by using standard solid phase Fmoc synthesis strategy and purified to more than $95 \%$ purity by reverse phasehigh performance liquid chromatography (RPHPLC). Their molecular weights were assessed by mass spectrometry [31]. For flow cytometry (FCM) binding assay, peptides were added with $G G G K$ biotin at carboxyl terminal. Peptide sequences were as follows: WPRFHSSVFHTHGGGK-biotin (WH-biotin); WPRFHSSVFHTHGGGSIINFEKL (WH-OVA ${ }_{257-264}$ ); GAGAAGGAGGGGGGGK-biotin (GA-biotin, control peptide) [32]; GAGAAGGAGGGGGGGSIINFEKL(GAOVA $\left._{257-264}\right)$; SIINFEKL(OVA $\left.257-264\right)$; WPRFHSSVFHTH (WH).

\section{Peptide binding assay by flow cytometry}

In brief, $5 \times 10^{5}$ FL-DCs or HEK-293T cells transfected with pIRES2-mClec9a were used. For all flow cytometry assays, the cells suspension was incubated with rat serum to block $\mathrm{Fc}$ receptors, and stained with corresponding antibody or biotin-peptides at $4^{\circ} \mathrm{C}$ for 30 $\mathrm{min}$, and then analyzed by flow cytometry after washing twice.

\section{In vitro cross presentation of $\mathrm{OVA}_{257-264}$ epitope by $\mathrm{DC}$}

In vitro peptide stimulation $\mathrm{T}$ cell assays were performed using a modification of a previously described protocol [32]. In brief, $10 \mu \mathrm{g} / \mathrm{mL}$ peptides 
(peptide-OVA $257-264, \mathrm{OVA}_{257-264}, \mathrm{WH}$ or NS) were incubated with FL-DC Day12 for $1.5 \mathrm{~h}$ at $4{ }^{\circ} \mathrm{C}$, by which the end time the peptide-loaded FL-DCs were washed three times. Meanwhile, OT-I CD8 ${ }^{+} \mathrm{T}$ cells were isolated using EasySep $^{\mathrm{TM}} \mathrm{CD}^{+} \mathrm{T}$ cell negative selection kit (Stemcell Technologies). Subsequently, the $\mathrm{CD}^{+} \mathrm{T}$ cells were seeded at $10^{5}$ cells per well at round-bottom 96-well plates for $30 \mathrm{~min}$. The peptide-loaded FL-DCs were then gently added at $10^{4}$ cells per well to the final volume of $200 \mu \mathrm{L}$. After incubation for $72 \mathrm{~h}$, Supernatants were assayed for IFN- $\gamma$ by ELISA. Perforin and granzyme mRNA expression were tested by qRT-PCR. The perforin forward and reverse primers are 5'-AGCACAAGTTCGTGCCA GG-3' and 5'-GCGTCTCTCATTAGGGAGTTTT T-3', respectively. The granzyme $\mathrm{B}$ forward and reverse primers are 5'-CCACTCTCGACCCTACATGG-3' and 5'- GGCCCCCAAAGTGACATTTATT-3', respectively. The $\beta$-actin forward and reverse primers are 5'-GTGGCATCCATGAAACT ACAT-3' and 5'GGCATAGAGGTCTTTACGG-3', respectively. For T cell proliferation assay, the $\mathrm{CD} 8^{+} \mathrm{T}$ cells were stained with $2 \mu \mathrm{M}$ CFSE. Three days later, $\mathrm{CD}^{+} \mathrm{T}$ cell proliferation was determined by CFSE dilution.

\section{CTL priming}

To test the peptide-OVA ${ }_{257-264}$ stimulation of CTL response, the peptide-OVA $257-264, \mathrm{WH}$ or $\mathrm{OVA}_{257-264}(100 \mu \mathrm{g}$ per mouse) were injected s.c. in the back of C57BL/6 mouse with $30 \mu \mathrm{g} \mathrm{CpG}$ ODN1826, as an adjuvant, for three times every 7 days internal. Five days after the last injection, ex vivo CTL assays were performed as described previously [3]. In brief, for re-stimulation of CTLs in vitro, splenocytes were incubated with $10 \mu \mathrm{g} /$ $\mathrm{mL} \mathrm{OVA}_{257-264}$ peptide for 5 days. The supernatant IFN- $\gamma$ was measured by ELISA. The perforin and granzyme B mRNA expression were tested by qRT-PCR. Meanwhile, the IFN- $\gamma$ release of CTLs were also determined by intracellular staining. Briefly, the re-stimulated splenocytes were added protein transport inhibitor cocktail for 7 hours, then those cells were stained with anti-CD3-PerCP-eFlour 710 (17A2) and anti-CD8-PE (53-6.7) for 30min at $4^{\circ} \mathrm{C}$. After the cells were fixed by fixation buffer (eBioscience) for another $30 \mathrm{~min}$ at room temperature and were washed twice by permeabilization wash buffer (eBioscience). Anti-IFN- $\gamma$-APC (XMG1.2) was added into those cells for intracellular staining for $30 \mathrm{~min}$ at $4{ }^{\circ} \mathrm{C}$. After being washed twice by permeabilization wash buffer, IFN- $\gamma$ released by $\mathrm{CD}^{+} \mathrm{T}$ cells was analyzed by flow cytometry.

\section{Tumor model}

The mice were received $9 \times 10^{5}$ B16-OVA cells i.v.. Three days later, these mice were injected weekly for 3 times with $100 \mu \mathrm{g}$ peptide-OVA ${ }_{257-264}$ /peptide $\mathrm{WH} / \mathrm{OVA}_{257}$ ${ }_{264}, 30 \mu \mathrm{g} / \mathrm{mouse} \mathrm{CpG}$ ODN 1826 as adjuvant. After 5 days of the last injection, these mice were sacrificed. Tumor burden was assessed by counting lung foci. Meanwhile, the splenocytes were pulsed with $10 \mu \mathrm{g} / \mathrm{mL} \mathrm{OVA}_{257-264}$ peptide for 5 days. The supernatant IFN- $\gamma$ was determined by ELISA. Also the CTL response were monitored as described above.

\section{ELISA for detection supernatant IFN- $\gamma$}

The experiment was according to the mouse IFNgamma ELISA Ready SET-Go kit (eBioscience). Briefly, ELISA plate (Costar) was coated with $100 \mu \mathrm{L} /$ well of IFN- $\gamma$ capture antibody overnight at $4{ }^{\circ} \mathrm{C}$. Next day, aspirate wells and wash 3 times with washing buffer (PBS pH7.2 with $0.05 \%$ Tween 20 ), then block with ELISA/ ELISPOT buffer 1 hour at room temperature. Serially diluted supernatant samples or IFN- $\gamma$ standard were added into wells and incubated for 2 hours at room temperature. Bound biotinylated IFN- $\gamma$ were detected using avidin-HRP and $1 \times \mathrm{TMB}$ solution. At the end time, $50 \mu \mathrm{L} /$ well Stop Solution was add and the plate was read at $450 \mathrm{~nm}$.

\section{Perforin and granzyme B mRNA expression by quantitative RT-PCR}

Total mRNA from cells were extracted by total mRNA kit (BeiBei Biology, China). Total mRNA reversely transcripted into cDNA using the Revert Aid cDNA synthesis kit (Themo Scientific, USA). PCR reactions were performed as following, $5 \mathrm{~min}$ at $65^{\circ} \mathrm{C}, 5$ min at $4^{\circ} \mathrm{C}$, followed by 2 two-step cycles of $60 \mathrm{~min}$ at $42^{\circ} \mathrm{C}$ and $5 \mathrm{~min}$ at $70^{\circ} \mathrm{C}$. Real-time PCR was performed by the relative standard curve method on Roche LightCycler 480 with LightCycler480 qRT-PCR mix according to the manufacturers' instructions. The PCR reaction were performed as following, $5 \mathrm{~min}$ at $94^{\circ} \mathrm{C}$ for pre-incubation, the detecting fluorescence was $15 \mathrm{~s}$ at $94^{\circ} \mathrm{C}, 1 \mathrm{~min}$ at $60^{\circ} \mathrm{C}$ for 45 cycles. At last the melting curve was $73^{\circ} \mathrm{C}$ to $95^{\circ} \mathrm{C}$, reading every $0.3^{\circ} \mathrm{C}$.

\section{Statistical analysis}

Statistical analysis was conducted with 1-tailed Student's t test for differences between groups. The data were shown as means \pm SEM unless otherwise stated. $* P<0.05, * * P<0.01$, and $* * * P<0.001$.

\section{ACKNOWLEDGMENTS}

We would like to thank Dr. Caetano Reis e Sousa and Kathryn Snelgrove for mClec9a plasmids.

\section{CONFLICTS OF INTEREST}

There are no conflicts of interest to disclosure. 


\section{GRANT SUPPORT}

This work was supported by the National Natural Science Foundation of China (81373228, 91442121, 81273228).

\section{REFERENCES}

1. Steinman RM. Lasker Basic Medical Research Award. Dendritic cells: versatile controllers of the immune system. Nature medicine. 2007; 13:1155-1159.

2. Shurin MR. Dendritic cells presenting tumor antigen. Cancer immunology, immunotherapy. 1996; 43:158-164.

3. Sancho D, Mourao-Sa D, Joffre OP, Schulz O, Rogers NC, Pennington DJ, Carlyle JR and Reis e Sousa C. Tumor therapy in mice via antigen targeting to a novel, DC-restricted C-type lectin. The Journal of clinical investigation. 2008; 118:2098-2110.

4. Iborra S, Izquierdo HM, Martinez-Lopez M, BlancoMenendez N, Reis e Sousa C and Sancho D. The DC receptor DNGR-1 mediates cross-priming of CTLs during vaccinia virus infection in mice. The Journal of clinical investigation. 2012; 122:1628-1643.

5. Caminschi I, Proietto AI, Ahmet F, Kitsoulis S, Shin Teh J, Lo JC, Rizzitelli A, Wu L, Vremec D, van Dommelen SL, Campbell IK, Maraskovsky E, Braley H, Davey GM, Mottram P, van de Velde N, et al. The dendritic cell subtyperestricted C-type lectin Clec9A is a target for vaccine enhancement. Blood. 2008; 112:3264-3273.

6. Swiggard WJ, Mirza A, Nussenzweig MC and Steinman RM. DEC-205, a 205-kDa protein abundant on mouse dendritic cells and thymic epithelium that is detected by the monoclonal antibody NLDC-145: purification, characterization, and $\mathrm{N}$-terminal amino acid sequence. Cellular immunology. 1995; 165:302-311.

7. Vremec D and Shortman K. Dendritic cell subtypes in mouse lymphoid organs: cross-correlation of surface markers, changes with incubation, and differences among thymus, spleen, and lymph nodes. Journal of immunology (Baltimore, Md : 1950). 1997; 159:565-573.

8. Brown GD, Taylor PR, Reid DM, Willment JA, Williams DL, Martinez-Pomares L, Wong SY and Gordon S. Dectin-1 is a major beta-glucan receptor on macrophages. The Journal of experimental medicine. 2002; 196:407-412.

9. Goodridge HS, Simmons RM and Underhill DM. Dectin-1 stimulation by Candida albicans yeast or zymosan triggers NFAT activation in macrophages and dendritic cells. Journal of immunology (Baltimore, Md : 1950). 2007; 178:3107-3115.

10. Huysamen C, Willment JA, Dennehy KM and Brown GD. CLEC9A is a novel activation C-type lectin-like receptor expressed on BDCA3+ dendritic cells and a subset of monocytes. The Journal of biological chemistry. 2008; 283:16693-16701.
11. Poulin LF, Salio M, Griessinger E, Anjos-Afonso F, Craciun L, Chen JL, Keller AM, Joffre O, Zelenay S, Nye E, Le Moine A, Faure F, Donckier V, Sancho D, Cerundolo V, Bonnet D, et al. Characterization of human DNGR-1+ BDCA3+ leukocytes as putative equivalents of mouse CD8alpha + dendritic cells. The Journal of experimental medicine. 2010; 207:1261-1271.

12. Kerrigan AM and Brown GD. Syk-coupled C-type lectin receptors that mediate cellular activation via single tyrosine based activation motifs. Immunological reviews. 2010; 234:335-352.

13. Lahoud MH, Ahmet F, Kitsoulis S, Wan SS, Vremec D, Lee CN, Phipson B, Shi W, Smyth GK, Lew AM, Kato Y, Mueller SN, Davey GM, Heath WR, Shortman K and Caminschi I. Targeting antigen to mouse dendritic cells via Clec9A induces potent CD4 $\mathrm{T}$ cell responses biased toward a follicular helper phenotype. Journal of immunology (Baltimore, Md : 1950). 2011; 187:842-850.

14. Park HY, Light A, Lahoud MH, Caminschi I, Tarlinton DM and Shortman K. Evolution of B cell responses to Clec9Atargeted antigen. Journal of immunology (Baltimore, Md : 1950). 2013; 191:4919-4925.

15. Ahrens S, Zelenay S, Sancho D, Hanc P, Kjaer S, Feest C, Fletcher G, Durkin C, Postigo A, Skehel M, Batista F, Thompson B, Way M, Reis e Sousa C and Schulz O. F-actin is an evolutionarily conserved damage-associated molecular pattern recognized by DNGR-1, a receptor for dead cells. Immunity. 2012; 36:635-645.

16. Zhang JG, Czabotar PE, Policheni AN, Caminschi I, Wan SS, Kitsoulis S, Tullett KM, Robin AY, Brammananth R, van Delft MF, Lu J, O'Reilly LA, Josefsson EC, Kile BT, Chin WJ, Mintern JD, et al. The dendritic cell receptor Clec9A binds damaged cells via exposed actin filaments. Immunity. 2012; 36:646-657.

17. Hanc P, Fujii T, Iborra S, Yamada Y, Huotari J, Schulz O, Ahrens S, Kjaer S, Way M, Sancho D, Namba K and Reis e Sousa C. Structure of the Complex of F-Actin and DNGR-1, a C-Type Lectin Receptor Involved in Dendritic Cell Cross-Presentation of Dead Cell-Associated Antigens. Immunity. 2015; 42:839-849.

18. Picco G, Beatson R, Taylor-Papadimitriou J and Burchell JM. Targeting DNGR-1 (CLEC9A) with antibody/MUC1 peptide conjugates as a vaccine for carcinomas. European journal of immunology. 2014; 44:1947-1955.

19. Palucka K and Banchereau J. Cancer immunotherapy via dendritic cells. Nature reviews Cancer. 2012; 12:265-277.

20. Figdor CG, de Vries IJ, Lesterhuis WJ and Melief CJ. Dendritic cell immunotherapy: mapping the way. Nature medicine. 2004; 10:475-480.

21. Tada F, Abe M, Hirooka M, Ikeda Y, Hiasa Y, Lee Y, Jung NC, Lee WB, Lee HS, Bae YS and Onji M. Phase I/II study of immunotherapy using tumor antigen-pulsed dendritic cells in patients with hepatocellular carcinoma. International journal of oncology. 2012; 41:1601-1609. 
22. Hawiger D, Inaba K, Dorsett $Y$, Guo M, Mahnke K, Rivera M, Ravetch JV, Steinman RM and Nussenzweig MC. Dendritic cells induce peripheral $\mathrm{T}$ cell unresponsiveness under steady state conditions in vivo. The Journal of experimental medicine. 2001; 194:769-779.

23. Bonifaz L, Bonnyay D, Mahnke K, Rivera M, Nussenzweig $\mathrm{MC}$ and Steinman RM. Efficient targeting of protein antigen to the dendritic cell receptor DEC-205 in the steady state leads to antigen presentation on major histocompatibility complex class I products and peripheral CD8+ T cell tolerance. The Journal of experimental medicine. 2002; 196:1627-1638.

24. Bonifaz LC, Bonnyay DP, Charalambous A, Darguste DI, Fujii S, Soares H, Brimnes MK, Moltedo B, Moran TM and Steinman RM. In vivo targeting of antigens to maturing dendritic cells via the DEC-205 receptor improves T cell vaccination. The Journal of experimental medicine. 2004; 199:815-824.

25. Buhler J, Gietzen S, Reuter A, Kappel C, Fischer K, Decker S, Schaffel D, Koynov K, Bros M, Tubbe I, Grabbe S and Schmidt M. Selective uptake of cylindrical poly(2oxazoline) brush-antiDEC205 antibody-OVA antigen conjugates into DEC-positive dendritic cells and subsequent T-cell activation. Chemistry (Weinheim an der Bergstrasse, Germany). 2014; 20:12405-12410.

26. Sancho D, Joffre OP, Keller AM, Rogers NC, Martinez D, Hernanz-Falcon P, Rosewell I and Reis e Sousa C. Identification of a dendritic cell receptor that couples sensing of necrosis to immunity. Nature. 2009; 458:899-903.
27. LeibundGut-Landmann S, Gross O, Robinson MJ, Osorio F, Slack EC, Tsoni SV, Schweighoffer E, Tybulewicz V, Brown GD, Ruland J and Reis e Sousa C. Syk- and CARD9-dependent coupling of innate immunity to the induction of $\mathrm{T}$ helper cells that produce interleukin 17 . Nature immunology. 2007; 8:630-638.

28. Reid DM, Gow NA and Brown GD. Pattern recognition: recent insights from Dectin-1. Current opinion in immunology. 2009; 21:30-37.

29. Durant LR, Pereira C, Boakye A, Makris S, Kausar F, Goritzka $\mathrm{M}$ and Johansson C. DNGR-1 is dispensable for $\mathrm{CD} 8+\mathrm{T}$-cell priming during respiratory syncytial virus infection. European journal of immunology. 2014; 44:2340-2348.

30. Chang HN, Liu BY, Qi YK, Zhou Y, Chen YP, Pan KM, Li WW, Zhou XM, Ma WW, Fu CY, Qi YM, Liu L and Gao YF. Blocking of the PD-1/PD-L1 Interaction by a D-Peptide Antagonist for Cancer Immunotherapy. Angewandte Chemie (International ed in English). 2015; 54:11760-11764.

31. Zhu YH, Gao YF, Chen F, Liu W, Zhai MX, Zhai WJ, Qi $\mathrm{YM}$ and Ye Y. Identification of novel T cell epitopes from efflux pumps of Mycobacterium tuberculosis. Immunology letters. 2011; 140:68-73.

32. Sioud M, Skorstad G, Mobergslien A and Saeboe-Larssen $\mathrm{S}$. A novel peptide carrier for efficient targeting of antigens and nucleic acids to dendritic cells. FASEB J. 2013; 27:3272-3283. 